Al-Azhar Bull. Sci. Vol. 21, No. 1 (June.): pp. 1-11, 2010.

\title{
SURVEY AND POPULATION STUDIES OF INSECTS \\ ASSOCIATED WITH ORNAMENTAL PLANTS BY USING \\ SWEEPING NETS AND PITFALL TRAPS AT RIYADH \\ METROPOLIS, SAUDI ARABIA
}

\author{
ALI ABDULLAH EL-GHARBAWY \\ Zoology department, Faculty of Science, Al-Azhar University, Cairo, \\ Egypt \\ Email: d_ali_20062000@yahoo.com
}

\begin{abstract}
A survey along with some studies on the population densities and relative abundance of insects associated with ornamental plants were conducted using sweeping nets and pitfall traps in Riyadh metropolis, Saudi Arabia, for a full year from December, 2006 to November, 2007. A total number of 2411 individuals, included thirty three species belonging to thirty genera, fifteen families and five orders, i.e. Coleoptera, Homoptera, Hemiptera, Hymenoptera and Orthoptera, were collected by the two methods. The largest numbers were observed during May, June and April. Also the largest number of species was belonging to the order Coleoptera (16 species), followed by the hymenopterans (7 species). Other orders were represented by varying number of species. The coleopterans were found to be the most abundant and dominant, constituting the majority of the catch (961 specimens, representing $39.9 \%$ of the total catch), followed by hymenopteran individuals (939 specimens, constituting $38.9 \%$ of the total catch). Insects of other orders were less abundant and were represented by small numbers of individuals, with the hemipterans constituting the minority of catch (4 specimens of two species).
\end{abstract}

Fifteen species belonging to fourteen genera, ten families and five orders were obtained throughout the year by using sweeping nets. While nineteen species belonging seventeen genera, six families and three orders were collected by pitfall trap.

\section{Introduction}

Surveying and studying populations, fluctuations and relative abundance of economic insects in some local areas are of significant value in insect pest management programs and give guide for further faunal studies. Two of the most convenient methods of carrying out such studies is by pitfall traps and sweeping nets which can be used in green houses, homes, orchards, flowers and vegetable gardens and everywhere that insects become annoying.

As ornamental plants enrich our lives every day and improve our environment, many authors reported in details some serious insect pests associated with these 
plants(Ellis et al., 2005; Moore and Hanks, 2004; Held and Potter, 2004 and Triplehorn and Johnson, 2005).

In Saudi Arabia, Al Maqooshy (1996) surveyed the aphids of ornamental plant in Riyadh region, recording 18 species of aphids associated with 74 ornamental plant species. Also, Al Ahmad (1989) surveyed the scale insects in the same region and studied the population dynamics and natural enemies of the dominant species. Ayoub (1959) discussed the insect pests of Saudi Arabia together with recommendations for their control. Issa and Helal (2000), Ali and El Saedy (1999), Hammad et al. (1965), Gafaar (1995), Al- Rajwy (1998) and Al-Menshawy and Hejazy (2001) surveyed and discussed the insect pests of the ornamental plants in some Arabian regions. The present work provide a survey together with same studies on population of insects associated with ornamental plants in Riyadh metropolis; Saudi Arabia by the pitfall traps and sweeping nets.

\section{Materials And Methods}

This study was conducted for surveying and studying the population of insects associated with ornamental plants in Riyadh metropolis throughout a whole year (December, 2006 - November, 2007). Nine locations under investigation, each contains five gardens were selected for this study. These were: Olaya (36500 $\mathrm{m}^{2}$ ), Western area $\left(45100 \mathrm{~m}^{2}\right)$, Malaz $\left(51900 \mathrm{~m}^{2}\right)$, Eastern area $\left(60300 \mathrm{~m}^{2}\right)$, Rotate A $\left(70000 \mathrm{~m}^{2}\right)$, Rotate B $\left(66250 \mathrm{~m}^{2}\right)$, Northern area $\left(69053 \mathrm{~m}^{2}\right)$, Southern area $(74100$ $\mathrm{m}^{2}$ ) and Shemasi area $\left(44590 \mathrm{~m}^{2}\right)$. Two collecting methods, in this study, sweeping nets and pitfall traps. In the first method were used the standard insect nets made in USA by BioQuip company were used. In the second method, pitfall trap, was used as a plastic bottle of water, 1.5 liters. Then dig a hole at a depth of $40 \mathrm{~cm}$ to put the trap where, buried in the trap where the hole trap at the level of the soil surface. Number of 10 pitfall traps at each site were calculated.

In the laboratory the insects removed carefully from the traps and sorted, identified, counted and recorded. Data calculations of their annual numbers and percentages of abundance, were provided.

Metrological data of average monthly temperature and average monthly humidity during the period of the study are as follows: 
SURVEY AND POPULATION STUDIES OF INSECTS ASSOCIATED ... 3

\begin{tabular}{|l|c|c|}
\hline \multicolumn{1}{|c|}{ Months } & Temperature (Avg.) & Humidity(Avg.) \\
\hline December 2006 & 16.53 & $59.54 \%$ \\
\hline January 2007 & 11.22 & $42.47 \%$ \\
\hline February2007 & 12.00 & $48.84 \%$ \\
\hline March 2007 & 19.52 & $26.78 \%$ \\
\hline April 2007 & 31.59 & $22.57 \%$ \\
\hline May 2007 & 34.85 & $26.05 \%$ \\
\hline June 2007 & 34.43 & $14.08 \%$ \\
\hline July 2007 & 37.03 & $15.43 \%$ \\
\hline August 2007 & 36.12 & $12.52 \%$ \\
\hline September 2007 & 33.49 & $16.06 \%$ \\
\hline October 2007 & 25.46 & $22.16 \%$ \\
\hline November 2007 & 23.90 & $33.09 \%$ \\
\hline
\end{tabular}

All taxa (Families, Genera and species) were arranged alphabetically according to their taxonomic position. Insects were identified based on identification keys, materials kept in the insect collection of the Plant Protection Department, College of Food and Agriculture Science, King Saud University and the collection of Regional Centre for Research on Agriculture and Water Ministry of Agriculture, KSA, and by special taxonomists in UK, USA and Egypt.

\section{Results and Discussion}

Survey of the insects associated with the ornamental plants of Riyadh city public gardens during a full year (December 2006- November 2007) using sweeping nets and pitfall traps revealed the presence of thirty three insect species within thirty genera of fifteen families in five orders. These species are alphabetically arranged according to orders, families and species and they are listed with the locality in table (1), sweeping net with months in table (2) and pitfall traps with months in table (3) together with their numbers. 
From these tables, the order Coleoptera formed the largest number of species (sixteen species within five families), order Hymenoptera (seven species of four families), order Homoptera (five species of two families), Orthoptera (three species of three families), whereas order Hemiptera represented by two species.

From table (1), the highest number of species was trapped from Southern and Shemasi locations (16 species for each), followed by Eastern, Rotate road A. and Rotate road B locations (each 13 species), then Olaya location (12 species). The lowest number of species was trapped from Western, Malaz and Northern locations (9 species).

It is to be noted that only three species were trapped from eight locations, these were Gonocephalum soricinum (Coleoptera: Tenebrionidae), Apis florae (Hymenoptera: Apidae) and Polistes watti (Hymenoptera: Vespidae); three species from seven locations, these are: Mesostena puncticollis and Gonocephalum orientalis (Coleoptera: Tenebrionidae) and Camponotus sp. (Hymenoptera: Formicidae); one species from six locations, Aiolopus sp. (Orthoptera: Acrididae); two species from five locations, namely: Gonocephalum soricinum (Coleoptera: Tenebrionidae) and Cataglyphis harteni (Hymenoptera: Formicidae) and two species were trapped from four different locations, which were Adesmia cancellata and Opatroides punctulatus (Coleoptera: Tenebrionidae) . On the other hand, two and three locations recorded 8 species for each, while five different species were trapped from two different locations.

Also, the data indicates that the highest number of insects were trapped from Shemasi location (661 specimens), followed by Southern location (450 specimens), and Eastern location (406 specimens), and then Rotate road A location (220 specimens), Considerable numbers were trapped from Malaz, Northern and Rotate road B locations (213, 156 and 140 specimens, respectively), the lowest numbers were obtained from Olaya and Western locations (93 and 72 insects, respectively).

From table (2), the total number of trapped insects by sweeping net 756 individuals, the highest numbers of insects were obtained during June, May and April (301, 131and 107 individuals, respectively), while the relatively lowest numbers during July, August, November and September (10, 21, 23 and 25 individuals, respectively). Relatively small numbers were collected during, February, March, October and December (36, 35, 32, and 28 individuals, 
SURVEY AND POPULATION STUDIES OF INSECTS ASSOCIATED ... 5 respectively) and the very few individuals were trapped during January (7 individuals only). The largest number of individuals attributed to order Homoptera (483 individuals, representing 63.89\% of the total annual catch), these insects were highly active and most abundant during the period from April to June with two major peaks of abundance during April and June (78 and 260 insects, respectively), followed by insects of order Hymenoptera (242 individuals, constituting 32.01\% of the total catch), nearly the majority of these insects were trapped during March to June with two major peaks of abundance during May and June (55 and 34 insects, respectively). Orders: Orthoptera, Coleoptera, and Hemiptera were represented by smaller number of individuals (21, 6 and 4 individuals, constituting 2.78\%, 0.79\% and $0.52 \%$ of the total catch, respectively).

The cicadellid species, Nephotettix cincticeps, was the most abundant and dominant of all species, with a total annual number of 146 individuals, constituting $19.31 \%$ of the total annual catch, individuals of this species were largely active and most frequent during April and May (32 and 71 individuals, respectively). Delphacodes sp.came next in abundance with nearly equal numbers (136 individuals), active and most frequent during months April and June (38 and 89 individuals, respectively).

Table (3), show the species collected by pitfall traps, the total number of trapped insects was 1655 individuals, the highest numbers of insects were obtained during May, June and January (524, 178and 172 individuals, respectively), while the relatively lowest numbers during November, February, September and March (58, 70, 72 and 80 individuals, respectively). Relatively small numbers were trapped during April, December, August and October (138, 132, 98 and 94 individuals, respectively) and the very few individuals during July (39 individuals only). The largest number of individuals was belonged to order Coleoptera (955 individuals, representing $57.7 \%$ of the total annual catch), these insects were highly active and most abundant during the period from April to October with two major peaks of abundance during May and June (199 and 169 insects, respectively), followed by insects of order Hymenoptera (697 individuals, constituting $42.11 \%$ of the total catch), nearly the majority of these insects were trapped during December to May with two major peaks of abundance during January and May (161 and 325 insects, respectively). Order Orthoptera was represented by smaller number of individuals (3 individuals, constituting $0.18 \%$ of the total catch). The formicid species, Camponotus maculates, was the most abundant and dominant of all species, with a 
total annual number of 502 individuals, constituting $30.33 \%$ of the total annual catch, individuals of this species were largely active and most frequent during January and May (128 and 300 individuals, respectively). The tenebrionid species, Mesostena puncticollis, came next in abundance with nearly equal numbers (396 individuals, constituting 23.9\%), active and most frequent during months February to November. Individuals of the species Thriptera crinita, Opatroides punctulatus, Gonocephalum orientalis, Gonocephalum soricinum (Tenebrionidae, Coleoptera) and Camponotus sp.( Formicidae, Hymenoptera) were trapped in considerable numbers (137, 121, 69, 60, and 155 individuals, respectively). Other surveyed species were trapped in relatively very low numbers.

From the previous data of this study, it is suggested, the increase of the individuals in May probably because the prevailing climatic conditions were suitable at these month, but they were harsh during summer months. While the decrease number of individuals is due to these locations received low treatments of insecticides since they're located in highly population where the use of insecticides is limited.

Table (1): Numbers of species caught per Units

\begin{tabular}{|c|c|c|c|c|c|c|c|c|c|c|c|}
\hline Order, Family \& species & $\frac{\pi}{0}$ & $\begin{array}{l}\dot{\vec{s}} \\
3\end{array}$ & $\frac{\pi}{\frac{\pi}{\pi}}$ & 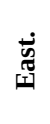 & 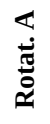 & $\begin{array}{l}n \\
\dot{\pi} \\
\dot{0}\end{array}$ & $\begin{array}{l}\dot{z} \\
\dot{0} \\
z\end{array}$ & 訔 & $\begin{array}{l}\overline{\tilde{n}} \\
\overline{\tilde{E}} \\
\overline{\tilde{E}}\end{array}$ & సँّ & $\%$ \\
\hline Coleoptera, Tenebrionidae & - & - & - & - & - & - & - & - & - & - & - \\
\hline Mesostena puncticollis & 5 & 3 & 0 & 38 & 32 & 0 & 6 & 212 & 100 & 396 & 16.42 \\
\hline Thriptera crinita & 3 & 1 & 0 & 3 & 38 & 25 & 0 & 57 & 10 & 137 & 5.68 \\
\hline Gonocephalum orientalis & 11 & 1 & 1 & 8 & 4 & 8 & 0 & 35 & 1 & 69 & 2.86 \\
\hline Gonocephalum soricinum & 0 & 8 & 0 & 7 & 5 & 0 & 0 & 9 & 31 & 60 & 2.49 \\
\hline Adesmia cancellata & 0 & 0 & 0 & 25 & 0 & 1 & 0 & 8 & 9 & 43 & 1.78 \\
\hline Opatroides punctulatus & 0 & 0 & 0 & 36 & 37 & 3 & 0 & 45 & 0 & 121 & 5.02 \\
\hline Trachyderma philistina & 0 & 0 & 0 & 0 & 22 & 2 & 0 & 17 & 0 & 41 & 1.70 \\
\hline Pimelia arabica & 0 & 0 & 0 & 1 & 0 & 0 & 1 & 1 & 0 & 3 & 0.12 \\
\hline Oxycara sp. & 0 & 0 & 0 & 0 & 34 & 3 & 0 & 8 & 0 & 45 & 1.87 \\
\hline Alphitobius sp. & 0 & 0 & 0 & 0 & 5 & 0 & 0 & 0 & 0 & 5 & 0.21 \\
\hline Tribolium confusum & 0 & 0 & 0 & 0 & 0 & 3 & 0 & 0 & 21 & 24 & 1.0 \\
\hline Coleoptera, Scarabaeidae & - & - & - & - & - & - & - & - & - & - & - \\
\hline Pentodon algerinum & 0 & 1 & 0 & 0 & 0 & 0 & 0 & 3 & 3 & 7 & 0.29 \\
\hline Hybosorus illigeri & 0 & 2 & 0 & 0 & 0 & 0 & 0 & 0 & 0 & 2 & 0.08 \\
\hline Coleoptera, Carabidae & - & - & - & - & - & - & - & - & - & - & - \\
\hline
\end{tabular}


SURVEY AND POPULATION STUDIES OF INSECTS ASSOCIATED ... 7

\begin{tabular}{|l|c|c|c|c|c|c|c|c|c|c|c|}
\hline & & & & & & & & & & & \\
\hline Bembidion sp. & 0 & 0 & 0 & 0 & 1 & 0 & 0 & 0 & 2 & 3 & 0.12 \\
\hline Coleoptera, Bruchidae & - & - & - & - & - & - & - & - & - & - & - \\
\hline
\end{tabular}


Table (1): Cont.

\begin{tabular}{|c|c|c|c|c|c|c|c|c|c|c|c|}
\hline Pachymerus gonager & 1 & 0 & 3 & 0 & 0 & 0 & 0 & 0 & 0 & 4 & 0.17 \\
\hline Coleoptera, Coccinellidae & - & - & - & - & - & - & - & - & - & - & - \\
\hline Coccinella undecimpunctata & 1 & 0 & 0 & 0 & 0 & 0 & 0 & 0 & 0 & 1 & 0.04 \\
\hline Homoptera, Cicadellidae & - & - & - & - & - & - & - & - & - & - & - \\
\hline Empoasca lybica & 0 & 0 & 0 & 0 & 3 & 76 & 0 & 20 & 0 & 99 & 4.11 \\
\hline Balclutha hortensis & 15 & 0 & 0 & 0 & 0 & 0 & 75 & 4 & 0 & 94 & 3.9 \\
\hline Nephottetix cincticeps & 31 & 0 & 115 & 0 & 0 & 0 & 0 & 0 & 0 & 146 & 6.06 \\
\hline Homoptera, Delphacidae & - & - & - & - & - & - & - & - & - & - & - \\
\hline Delphacodes sp. & 0 & 0 & 0 & 75 & 0 & 0 & 38 & 0 & 23 & 136 & 5.64 \\
\hline Toya propinqua & 0 & 0 & 0 & 0 & 0 & 0 & 0 & 8 & 0 & 8 & 0.33 \\
\hline Hemiptera, Pentatomidae & - & - & - & - & - & - & - & - & - & - & - \\
\hline Nezara viridula & 0 & 0 & 2 & 0 & 0 & 0 & 0 & 0 & 0 & 2 & 0.08 \\
\hline Eysarcoris inconspicuus & 0 & 0 & 2 & 0 & 0 & 0 & 0 & 0 & 0 & 2 & 0.08 \\
\hline Hymenoptera, Apidae & - & - & - & - & - & - & - & - & - & & - \\
\hline Apis mellifica & 7 & 0 & 0 & 0 & 0 & 0 & 0 & 0 & 3 & 10 & 0.41 \\
\hline Apis florea & 6 & 14 & 23 & 5 & 4 & 11 & 2 & 0 & 26 & 91 & 3.77 \\
\hline Hymenoptera, Scoliidae & - & - & - & - & - & - & - & - & - & & - \\
\hline Dielis collaris & 10 & 0 & 0 & 0 & 0 & 0 & 0 & 0 & 0 & 10 & 0.41 \\
\hline Hymenoptera, Vespidae & - & - & - & - & - & - & - & - & - & & - \\
\hline Polistes wattii & 0 & 25 & 14 & 7 & 24 & 3 & 25 & 12 & 21 & 131 & 5.43 \\
\hline Hymenoptera, Formicidae & - & - & - & - & - & - & - & - & - & & - \\
\hline Camponotus maculatus & 0 & 12 & 21 & 0 & 0 & 0 & 0 & 0 & 7 & 40 & 1.66 \\
\hline Camponotus sp. & 2 & 5 & 0 & 42 & 11 & 0 & 0 & 0 & 95 & 155 & 6.43 \\
\hline Cataglyphis harteni & 0 & 0 & 32 & $\begin{array}{c}15 \\
2\end{array}$ & 0 & 3 & 7 & 0 & 308 & 502 & 20.82 \\
\hline Orthoptera, Gryllidae & - & - & - & - & - & - & - & - & - & & - \\
\hline Gryllus domesticus & 0 & 0 & 0 & 0 & 0 & 1 & 0 & 0 & 0 & 1 & 0.04 \\
\hline Orthoptera, Gryllotalpidae & - & - & - & - & - & - & - & - & - & & - \\
\hline Gryllotalpa gryllotalpa & 0 & 0 & 0 & 0 & 0 & 0 & 1 & 1 & 0 & 2 & 0.08 \\
\hline Orthoptera, Acrididae & - & - & - & - & - & - & - & - & - & & - \\
\hline Aiolopus sp. & 1 & 0 & 0 & 7 & 0 & 1 & 1 & 10 & 1 & 21 & 0.87 \\
\hline Total & 93 & 72 & 213 & 406 & 220 & 140 & 156 & 450 & 661 & 2411 & - \\
\hline
\end{tabular}




\section{SURVEY AND POPULATION STUDIES OF INSECTS ASSOCIATED ... 9}

Table (2): Numbers of species caught per months by sweeping net

\begin{tabular}{|c|c|c|c|c|c|c|c|c|c|c|c|c|c|c|}
\hline $\begin{array}{l}\text { Order, Family } \\
\text { \& species }\end{array}$ & ڤ̆ & 空 & $\dot{0}$ & 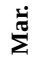 & 荌 & $\sum^{\overparen{m}}$ & 㤩 & $\dot{\Xi}$ & 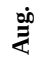 & षें & $\ddot{\Xi}$ & zे & సٓㅠㄹ & $\%$ \\
\hline Coleoptera, Carabidae & - & - & - & - & - & - & - & - & - & - & - & - & - & - \\
\hline Bembidion sp. & 0 & 0 & 0 & 0 & 0 & 0 & 0 & 1 & 0 & 0 & 0 & 0 & 1 & 0.13 \\
\hline Coleoptera, Bruchidae & - & - & - & - & - & - & - & - & - & - & - & - & - & - \\
\hline Pqchymerus gonager & 0 & 0 & 0 & 0 & 0 & 1 & 3 & 0 & 0 & 0 & 0 & 0 & 4 & 0.53 \\
\hline $\begin{array}{l}\text { Coleoptera, } \\
\text { Coccinellidae }\end{array}$ & - & - & - & - & - & - & - & - & - & - & - & - & - & - \\
\hline $\begin{array}{l}\text { Cфccinella } \\
\text { undecimpunctata }\end{array}$ & 0 & 0 & 0 & 0 & 0 & 0 & 1 & 0 & 0 & 0 & 0 & 0 & 1 & 0.13 \\
\hline $\begin{array}{l}\text { Homoptera, } \\
\text { Cicadellidae }\end{array}$ & - & - & - & - & - & - & - & - & - & - & - & - & - & - \\
\hline Eqpoasca lybica & 3 & 0 & 0 & 0 & 0 & 0 & 96 & 0 & 0 & 0 & 0 & 0 & 99 & 13.1 \\
\hline Bdlclutha hortensis & 0 & 0 & 4 & 0 & 0 & 0 & 67 & 0 & 15 & 0 & 0 & 8 & 94 & 12.43 \\
\hline Nephotettix cincticeps & 3 & 7 & 11 & 13 & 32 & 71 & 8 & 0 & 1 & 0 & 0 & 0 & 146 & 19.31 \\
\hline $\begin{array}{l}\text { Homoptera, } \\
\text { Delphacidae }\end{array}$ & - & - & - & - & - & - & - & - & - & - & - & - & - & - \\
\hline Delphacodes sp. & 0 & 0 & 0 & 0 & 38 & 0 & 89 & 0 & 0 & 9 & 0 & 0 & 136 & 17.99 \\
\hline тоула propinqua & 0 & 0 & 0 & 0 & 8 & 0 & 0 & 0 & 0 & 0 & 0 & 0 & 8 & 1.06 \\
\hline $\begin{array}{l}\text { Hemiptera, } \\
\text { Pentatomidae }\end{array}$ & - & - & - & - & - & - & - & - & - & - & - & - & - & - \\
\hline$N$ ezara viridula & 0 & 0 & 0 & 0 & 0 & 0 & 2 & 0 & 0 & 0 & 0 & 0 & 2 & 0.26 \\
\hline Eysarcoris inconspicuus & 0 & 0 & 0 & 0 & 0 & 2 & 0 & 0 & 0 & 0 & 0 & 0 & 2 & 0.26 \\
\hline Hymenoptera, Apidae & - & - & - & - & - & - & - & - & - & - & - & - & - & - \\
\hline Apis mellifica & 0 & 0 & 0 & 0 & 0 & 3 & 4 & 0 & 0 & 3 & 0 & 0 & 10 & 1.32 \\
\hline Apis florea & 0 & 0 & 21 & 17 & 8 & 27 & 12 & 0 & 0 & 0 & 6 & 0 & 91 & 12.04 \\
\hline Hymenoptera, Scoliidae & - & - & - & - & - & - & - & - & - & - & - & - & - & - \\
\hline Dielis collaris & 0 & 0 & 0 & 0 & 0 & 0 & 0 & 0 & 0 & 0 & 10 & 0 & 10 & 1.32 \\
\hline Hymenoptera, Vespidae & - & - & - & - & - & - & - & - & - & - & - & - & - & - \\
\hline Polistes wattii & 15 & 0 & 0 & 5 & 21 & 25 & 18 & 9 & 5 & 7 & 12 & 14 & 131 & 17.33 \\
\hline Othoptera, Acrididae & - & - & - & - & - & - & - & - & - & - & - & - & - & - \\
\hline Aiplopus sp. & 7 & 0 & 0 & 0 & 0 & 2 & 1 & 0 & 0 & 6 & 4 & 1 & 21 & 2.78 \\
\hline Total & 28 & 7 & 36 & 35 & 107 & 131 & 301 & 10 & 21 & 25 & 32 & 23 & 756 & - \\
\hline
\end{tabular}


ALI ABDULLAH EL-GHARBAWY

Table (3): Numbers of species caught per months by pitfall traps

\begin{tabular}{|c|c|c|c|c|c|c|c|c|c|c|c|c|c|c|}
\hline $\begin{array}{l}\text { Order, Family \& } \\
\text { species }\end{array}$ & ڤัٌ & ్ㅗㅇ & $\dot{\vec{U}}$ & $\sum^{\stackrel{\pi}{\pi}}$ & $\dot{a}$ & $\sum^{\pi}$ & $\Xi$ & $\dot{\Xi}$ & 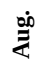 & ڤัं & $\tilde{\delta}$ & zे & हٓ & $\%$ \\
\hline $\begin{array}{l}\text { Coleoptera, } \\
\text { Tenebrionidae }\end{array}$ & - & - & - & - & - & - & - & - & - & - & - & - & - & - \\
\hline Mesostena puncticollis & 2 & 1 & 23 & 47 & 91 & 30 & 48 & 30 & 21 & 14 & 43 & 46 & 396 & 23.9 \\
\hline Thriptera crinita & 12 & 1 & 2 & 0 & 3 & 1 & 23 & 0 & 27 & 31 & 35 & 2 & 137 & 8.28 \\
\hline Gonocephalum orientalis & 0 & 5 & 3 & 0 & 1 & 12 & 19 & 2 & 13 & 9 & 5 & 0 & 69 & 4.17 \\
\hline Gonocephalum soricinum & 1 & 2 & 0 & 0 & 0 & 35 & 6 & 1 & 7 & 4 & 4 & 0 & 60 & 3.63 \\
\hline Adesmia cancellata & 0 & 0 & 5 & 4 & 8 & 0 & 25 & 0 & 0 & 0 & 0 & 1 & 43 & 2.6 \\
\hline Opatroides punctulatus & 0 & 0 & 2 & 0 & 5 & 73 & 5 & 0 & 20 & 12 & 4 & 0 & 121 & 7.31 \\
\hline Trachyderma philistina & 0 & 0 & 0 & 0 & 4 & 0 & 25 & 0 & 3 & 2 & 0 & 7 & 41 & 2.48 \\
\hline Pimelia arabica & 0 & 0 & 0 & 0 & 1 & 1 & 1 & 0 & 0 & 0 & 0 & 0 & 3 & 0.18 \\
\hline Oxycara $s p$ & 0 & 0 & 0 & 0 & 0 & 37 & 3 & 0 & 5 & 0 & 0 & 0 & 45 & 2.72 \\
\hline Alphitobius sp. & 0 & 0 & 0 & 0 & 0 & 5 & 0 & 0 & 0 & 0 & 0 & 0 & 5 & 0.30 \\
\hline Tribolium confusum & 0 & 0 & 1 & 1 & 3 & 2 & 14 & 2 & 1 & 0 & 0 & 0 & 24 & 1.45 \\
\hline Coleoptera, Scarabaeidae & - & - & - & - & - & - & - & - & - & - & - & - & - & - \\
\hline Pentodon algerinum & 1 & 2 & 0 & 0 & 0 & 1 & 0 & 0 & 0 & 0 & 3 & 0 & 7 & 0.42 \\
\hline Hybosorus illigeri & 0 & 0 & 0 & 0 & 0 & 2 & 0 & 0 & 0 & 0 & 0 & 0 & 2 & 0.12 \\
\hline Coleoptera, Carabidae & - & - & - & - & - & - & - & - & - & - & - & - & - & - \\
\hline Bembidion sp. & 0 & 0 & 0 & 2 & 0 & 0 & 0 & 0 & 0 & 0 & 0 & 0 & 2 & 0.12 \\
\hline Hymenoptera, Formicidae & - & - & - & - & - & - & - & - & - & - & - & - & - & - \\
\hline Camponotus maculatus & 33 & 7 & 0 & 0 & 0 & 0 & 0 & 0 & 0 & 0 & 0 & 0 & 40 & 2.42 \\
\hline Camponotus sp. & 16 & 26 & 34 & 18 & 22 & 25 & 9 & 4 & 1 & 0 & 0 & 0 & 155 & 9.37 \\
\hline Cataglyphus harteni & 67 & 128 & 0 & 7 & 0 & 300 & 0 & 0 & 0 & 0 & 0 & 0 & 502 & 30.33 \\
\hline Orthoptera, Gryllidae & - & - & - & - & - & - & - & - & - & - & - & - & - & - \\
\hline Gryllus domesticus & 0 & 0 & 0 & 1 & 0 & 0 & 0 & 0 & 0 & 0 & 0 & 0 & 1 & 0.06 \\
\hline Orthoptera, Gryllotalpidae & - & - & - & - & - & - & - & - & - & - & - & - & - & - \\
\hline Gryllotalpa gryllotalpa & 0 & 0 & 0 & 0 & 0 & 0 & 0 & 0 & 0 & 0 & 0 & 2 & 2 & 0.12 \\
\hline Total & 132 & 172 & 70 & 80 & 138 & 524 & 178 & 39 & 98 & 72 & 94 & 58 & 1655 & - \\
\hline
\end{tabular}

\section{References}

1. AL-AHMAD, A.M. (1989): Survey of scale insects of certain fruit and shade trees in Riyadh region, with special reference to the study of the population dynamics and natural enemies of the dominant species. Master thesis, Agriculture college, King Saud University. (125 pp.) (In Arabic).

2. ALI, M. A. AND A. AL-SAEDY (1999): Scientific guide for insect pests and their control. Al-Dar Al-Masreia Al-Lebnaneia. Egypt. 239 pp. (In Arabic).

3. AL-MAQOOSHY, A. (1996): Survey of Aphid insects on ornamental plants in Riyadh city, and the impact of the rates of nitrogen fertilization and irrigation on population density to it. M. Sc. Thesis, Agriculture faculty King Saud University -112 pp. (In Arabic).

4. AL- MENSHAWY A. AND E. HEJAZY (2001): Pests of insects and animals and their control. 1st ed., Almareef Library.Egypt- 687 pp. (In Arabic).

5. AL-RAJWY, A. (1998): Applied guide to pest control and plant diseases- Madbolli Library, Egypt. 334 pp. (In Arabic). 


\section{SURVEY AND POPULATION STUDIES OF INSECTS ASSOCIATED...11}

6. AYOUB M. (1959): Insects and Agricultural pests and control method in Saudi Arabia. Dar Al Feekr in Riyadh K S A (405 pp). (In Arabic).

7. ELLIS, J.A.; A.D. WALTER; J.F. TOOKER; M.D. GINZEL; P.F. REAGEL; E.S. LACEY; A. B. BENNETT; E.M. GROSSMAN AND L.M. HANKS (2005): Conservation biological control in urban landscapes: Manipulating parasitoids of bagworm (Lepidoptera: Psychidae) with Xowering forbs. Biological Control 34, 99-107.

8. FARAGAlLA, A. A. AND E. E. ADAM, (1985): Pitfall trapping of tenebrionid and carabid beetles (Coleoptera) in different habitats of the Central Region of Saudi Arabia. Z. ang. Ent. 99, 466- 471.

9. GAFAAR, B. (1995): Deseases and insects of vegetables and their control methods. Dar Al Marefa- Syria 253 pp. (In Arabic).

10. HAMAD, S.; H. EL-AROSSY AND M. ASSEM (1965): Pests and Vegetables diseases and its control. 1st ed. AlDar AlQawmeia for printing and Publishing. Egypt. 766 pp. (In Arabic).

11. HELD, D W. AND D.A. POTTER (2004): Floral characteristics affect susceptibility of hybrid tea roses, Rosa x hybrida, to Japanese beetles (Coleoptera: Scarabaeidae). J. Econ. Entomol. 97(2):353-60.

12. ISSA, I. AND H. HELAL (2000): Modern Methods in study of pests of Vegetables, ornamental and wood-trees and its control in Arabic world. Part III. Dar Al-Ketab AlHadeeth. Egypt. 363 pp. (In Arabic).

13. MOORE, R. AND L. HANKS (2004): Aerial dispersal and host plant selection by neonate Thyridopteryx ephemeraeformis (Lepidoptera: Psychidae). Ecological Entomology 29, 327-335.

14. TRIPLEHORN, C.A. AND N.F. JOHNSON (2005): Borror and Delong's Introduction to the study of insects. Seventh edition. Thomson Brooks/Cole. 864 pp. 


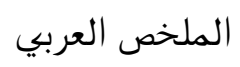

حصر وراسة التعداد الحشري للحثرات المصاحبة لنباتات الزينة باستخدام المربي

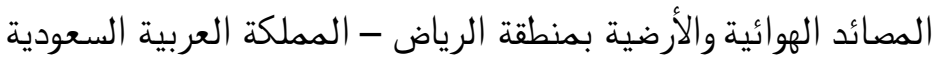

$$
\text { على عبدالله الغرباوي }
$$$$
\text { قسم علم الحيوان- كلية العلوم- جامعة الأزهر- القاهرة- مصر. }
$$

تم حصر ومراسة الكثافة العددية والوفرة النسبية للحشر ات باستخدام المصائد الهوائية

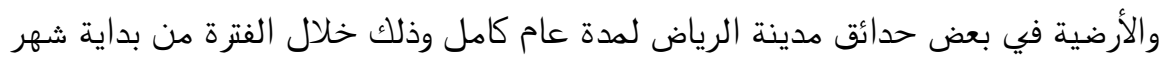

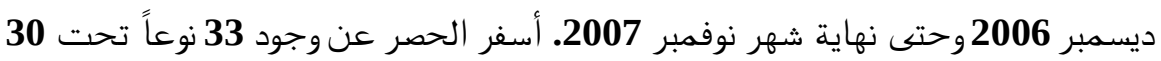

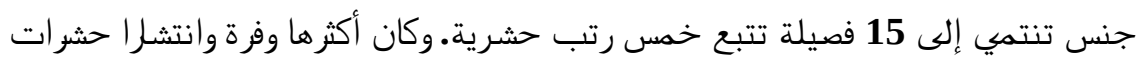
رتبة غمديه الأجنحة واحتلت أفراد النمل Cataglyphus harteni أعلي كثافة عددية في مجموع الحشرات حيث بلغت نسبتها 20.82 \% من المجموع الكلي للحشر ات (العـدم

$$
\text { الكلــ مجس } 2411 \text { حشرةً). }
$$

وقد لوحظ تجميع العدد الأكبر للحشرات في الفترة من ديسمبر إلى يونيو ووصلت إلى

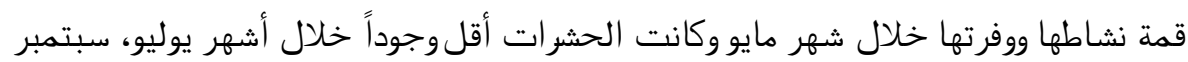


SURVEY AND POPULATION STUDIES OF INSECTS ASSOCIATED...13 